\title{
Premature Elective Replacement Indicator
}

National Cancer Institute

\section{Source}

National Cancer Institute. Premature Elective Replacement Indicator. NCI Thesaurus.

Code C63315.

Problems with the early or unexpected activation of the elective replacement indicator. 